\title{
DETERMINANT OF SMALL MEDIUM BUSINESS FUNDING DECISION IN BATU
} CITY

\section{Dwi Anggarani \\ Faculty of Economics, University of Widyagama Malang \\ Email: anggarani@widyagama.ac id}

Muchlis H. Mas'ud Faculty of Economics, University of Widyagama Malang

Zulkifli

Faculty of Economics, University of Widyagama Malang

\begin{abstract}
This study aims to examine the relationship between determinant variables affecting SME funding decision in Batu City. The approach used is survey research on perpetrators of SMEs excellent products as respondents to test the causality of variables affecting the funding decision. The analysis technique used is multiple regressions. The research found that: (1) although SMEs can achieve profit and increase assets, SMEs in Batu City prioritize internal funding sources. (2) Higher business risk due to increased company size and leverage operations. The SMEs tend to use internal funding rather than debt. SMEs growth does not necessarily use debt. Most the production activities of SMEs in Batu City have reached full capacity.
\end{abstract}

KEYWORD: profitability, business risk, company size, growth, tangibility..

\section{INTRODUCTION}

Batu City Economy currently has about 14,570 MSMEs actors to contribute $42 \%$ of local revenue (PAD). Identity of MSMEs of excellent products in region is closely related to regional autonomy and its relevance to absorption of local economic base to stimulate PAD, employment and empowerment of MSMEs. Developing the MSMEs excellent products can increases the competitive advantage (Kuncoro and Abimanyu in Soterato et al, 2011).

MSMEs have a significant contribution to economic growth. Hapsari et al (2014) found that SMEs growth based on business unit, the amount of labor, capital and profit variables influenced the economic growth of Batu City SMEs. Partially, capital and profit variables have significant influence on economic growth of Batu City. This means that capital and profit aspects of SMEs become the key variable of Batu economic growth. Therefore, each region is required to further increase its potential in order to improve the economy and regional competitiveness. The increased economy and competitiveness of region will be more significant for local governments if supported by SME growth.

It can be argued that generally the problems of SMEs today is the capital, production, human resources and marketing. These create weakness of business network, limited market penetration ability and market diversification, too small economics scale creates difficult to reduce cost, and very small profit margin. Therefore, each region is required to further increase its potential in order to improve the economy and regional 
competitiveness. The higher economy and competitiveness of region will be more significant for local governments if supported by SME growth.

SME business is an integral part of a country economy. Small people in their efforts to build micro business, small and medium enterprises (MSMEs) is currently supported by many parties, both government and private. Thus, MSMEs should also have independent skills and innovation to manage their business. Independence and innovation of SMEs will determine the fate of MSME itself. An enterprise in order to stay afloat and have strong competitiveness should pay attention to future business strategy and to arrange financial planning to increase company value. Financial planning is a function of financial management covering three main functions namely investment, funding and asset management decisions. Financial managers have an important role to implement these three functions to increase the wealth (value) for owners of company.

The classic problems of SMEs today are capital, production, human resources and marketing. These create weakness of business network, limited market penetration ability and market diversification, too small economics scale creates difficult to reduce cost, and very small profit margin. Barney (1991) said that companies become low performers because of insufficient resources related to financial performance of SMEs. Nguyen (2001) pointed out that efficient cash-flow management practices makes Vietnamese SMEs profitable. He found that inefficient financial management practices can lead to poor business performance of SMEs. This is because the financial management practices such as SME's cash management still depend on mindset and experience of owner. This is consistent with Raheman et al., (2008) and Degryse et al. (2011) to found that performance trends of SMEs in Spain and Pakistan relate to efficient working capital as a predictor of overall profitability and performance of SMEs.

The SMEs financial planning should focus on funding decisions. It will provide a direction for SMEs to determine the amount of funds owned, the funds source and ability to finance corporate strategy to increase the company value. Employers will use part of SME's financial to run the strategy. It needs financial decisions related to the funds source. Not all individual businesses / SMEs have their own assets to use in managing their business. Therefore, entrepreneurs need to use other sources of funds or debt as a funding decision to increase the company value and having a strong competitiveness. Modigliani and Miller (1963) examine this concept in light of tax that company value was affected by structure. Modigliani and Miller's theory has the support of several studies that have been conducted in a number of different countries that capital structure as a proxy for funding decisions was positively related to firm value (Pandey 2004, Rocca, 2007; Liu, 2007; Sumiati, 2011; and La Masidonda , 2012).

Based on above empirical studies, it is asserted that debt can have a positive effect, if SME debt usage can run its business and gain profit, where part of profit portion will be used to cover debt and some other portion used for use or for business expansion. Similarly, the debt usage can have a negative effect if debt management is bad. Sudarma (2004) and Sujono (2010) found that high debt usage by manufacturing industries in Indonesia decrease the company value. This evidence suggests that a financial entrepreneur's decision becomes absolutely essential. Skills to manage finances must be owned by large scale and small scale business entrepreneurs should have decisionmaking skills.

The important question in this paper is what the determinant factors for SMEs owners in determining funding decisions to achieve profitability and business continuity in future. These factors affect the composition of debt and capital structure. Practically, SMEs are more likely to use internal funding sources than external sources of funds. They have limited access to formal financial institutions (banks), due to inability of SMEs to prepare cash flow reports and good financial reports. 


\section{LITERATURE REVIEW}

\section{Funding Decisions}

Funding decision is about the decision on form and composition of the funding used by company. This is a financial management decision by considering the analysis of synthesis of most economically viable sources funds for firm to meet the investment needs and operational activities of company (Husnan and Pudjiastuti, 2006: 277). The availability of funds to fund these various investment alternatives can be seen from capital structure by observing the balance sheet on liabilities side. Funding decisions made by management will affect the company value as reflected in stock price. Therefore, one task of financial managers is to determine the policy or funding decision, which is also often referred to as the capital structure policy.

\section{Capital Structure}

Brigham and Daves (2010: 506) defined capital structure as "a combination of equity and debt". Furthermore, Sartono (2010: 225) said that "The capital structure is the balance of amount of short-term debt, long-term debt, preferred stock, and common stock". The balance between the debt and equity financing decisions will determine the size of debt or equity portion or financial composition of the company's assets.

Modern capital structure theory was first proposed by Modigliani and Miller (MM) in 1958 in his article entitled "The cost of capital, corporation finance, and theory of investment". It was the most influential financial article in financial theory. MM supports the capital structure theory of net operating income (NOI) approach and rejects traditional capital structure theory (Baral, 2004). MM proposes a proposition based on a limiting assumption that firm value does not depend on funding decisions or capital structure but it was determined by capitalization of expected return at some level. The MM proposition is theoretically very strong but it was based on assumption of a perfect and unpaid capital market, which in reality does not apply. Once the tax element is incorporated in MM model the view changes, as quoted by Brigham et al. (1999: 407-421). Modigliani and Miller's second study in 1963 argued that a funding or leverage decision would increase the company value because interest on debt reduces taxable income. Criticism of second MM is company value with $100 \%$ better than the company without debt. Companies that use $100 \%$ debt are rarely seen in practice, because there is a trade-off between the benefits of tax savings and cost of bankruptcy with debt usage (Brigham et al., 1999: 376). Nevertheless, MM provides direction or description on how funding decisions for capital structure become relevant and affect the company value. The study result from MM cause a long debate of financial management experts who finally gave birth to two competing theories and dominate the study of modern capital structure theory namely trade-off theory and pecking order theory.

\section{Determinant of Capital Structure}

The determinants affecting the capital structure are sales stability, asset structure, leverage of operations, growth rate, profitability, taxes, controls, management attitudes, market conditions, internal conditions and financial flexibility (Brigham and Houston, 2004). Theoretical and empirical studies suggest that within capital structure there are important determinant variables to affect the capital structure.

Previous theory and results of empirical studies suggested a determinant of capital structure that slightly different among researchers. It is adjusted to condition of data as the unit of analysis. Many researchers found the same variable as the determinant of capital structure. Huang and Song (2006) examine the relationship between profitability, tangibility, size, non-debt tax shield, growth opportunities, volatility and institutional ownership with capital structure. Furthermore, Akhtar and Oliver (2009) explored the relationship between business risks, age; collateral value of assets, free cash flow, and foreign exchange risks (exchange rate risk growth opportunities, non debt tax shield, political risk, profitability and size. Sumiati (2011) examine manufacturing companies listed 
on Indonesia Stock Exchange using determinant variable of capital structure include profitability, liquidity, company size, asset tangibility and non debt tax shield.

\section{Profitability}

Profitability shows the company's ability to generate profits to manage assets owned. Firms with high profitability indicate that company has been able to manage its resources effectively and efficiently. This is a guarantee for company to maintain its business continuity. Conversely, a company with low profitability shows the inability to manage its resources. Consequently, they unable earn a high profit.

Packing order theory explained that higher profitability of company drive the company to avoid debt to finance its investment. The company has a high internal source of funds from company. Packing order theory explained that companies will use their internal sources first before taking external sources of funds through debt. Thus, according to packing order theory, profitability has a negative effect on capital structure. The results of empirical studies that support packing order theory include Akhtar \& Oliver (2009), Crinigoj \& Mramor (2009), Huang \& Song (2006), Tong \& Green (2005), Chen (2002), and Pandey (2001). Return on assets (ROA) is profitability ratios often used in research related to capital structure.

\section{Company size}

Company size describes the size of a company expressed by total assets. Large companies have differences in funding decisions compared to small firms. According to trade-off theory, large corporations have the capacity to extract larger sources of debt funding than small firms. Therefore, large companies will tend to use large amounts of debt than small firms. The results of empirical studies that support trade-off theory include Akhtar \& Oliver (2009), Crinigoj \& Mramor (2009), Huang \& Song (2006), Gaud et al. (2006), Tong \& Green (2005), Chen ( 2004) and Pandey (2001). This paper measures the company size by natural log of total assets. These measurements correspond to measurements made in Akhtar and Oliver studies (2009), Zou \& Xiao (2006), Buferna (2005), Padron (2005) and Chen (2004).

\section{Tangibility}

Tangibility is defined as the ratio of fixed assets to total assets. This ratio shows how much the value of fixed assets that can be used as collateral by borrower on his debt to creditor. The guarantee will provide a sense of security for funds he lends if the company has financial difficulties. According to trade-off theory, firms with large amounts of tangible assets will have a great ability to provide guarantees for financing through debt. It can be said that companies with high tangibility will tend to use debt in financing their investment. According to trade-off theory, tangibility has a positive influence on capital structure. The results of empirical studies that support trade-off theory include Akhtar \& Oliver (2009), Crinigoj \& Mramor (2009), Huang \& Song (2006), Gaud et al. (2006), Zou \& Xiao (2006), Tong \& Green (2005), and Chen (2004). The measurement of tangibility in this paper is expressed as the ratio of fixed assets to total assets. These measurements are based on measurement of tangibility on Akhtar \& Oliver's research (2009), Huang \& Song (2006), Gaud et al. (2006), Buferna et al., (2005) and Padron (2005).

\section{Business Risk}

The Company has a number of risks directly attributable to type of business of enterprise. The business risk according to Brigham and Houston (2004) is how risky a company's stock is if the company does not use the debt. Business risk not only varies from industry to industry, but also can vary between companies from certain industries, and can also change over time. Companies that have large tangibility indicate that company has high operating leverage. Companies that have high operating leverage, basically have a greater chance of achieving higher levels of growth and profitability compared to companies with low tangibility. Because of high tangibility tend to use debt to finance the growth of company. However, companies that have large tangibility and are able to achieve high 
growth will face higher business risk than companies with low (small) tangibility. Thus the risk

Growth

Growth describes the growth rate of sales, asset or profit achieved by company each year. Companies with relatively high growth will be more likely to use debt to finance growth plans. This is because the company has the certainty of cash flow to pay or repay its debt to creditor. Thus it can be concluded that growth is positively related to debt usage (capital structure). Empirical studies that support this are Cathoth and Olsen (2007), Parlak (2010) study that found growth positively associated with debt usage.

\section{METHOD}

This survey research was conducted by collecting data in form of questionnaires consisting of a number of structured questions. The population is small and medium enterprises (SMEs) in Batu City, East Java. The samples were selected by non-random purposive sampling of 87 SMEs has been established for at least 1 year. The analytical technique used multiple regression analysis with SPSS for Windows 17 software.

\section{RESULTS AND DISCUSSION}

The classic assumption test shows that there is no multicollinearity, heteroskedasticity and autocorrelation. The regression test results are shown in table 1 below.

Table 1. Regression Analysis Results

\begin{tabular}{|c|c|c|c|c|c|c|c|c|}
\hline \multicolumn{9}{|c|}{ Coefficients ${ }^{a}$} \\
\hline & & \multicolumn{2}{|c|}{$\begin{array}{l}\text { Unstandardized } \\
\text { Coefficients }\end{array}$} & \multirow{2}{*}{$\begin{array}{c}\begin{array}{c}\text { Standardized } \\
\text { Coefficients }\end{array} \\
\text { Beta }\end{array}$} & \multirow[b]{2}{*}{$\mathrm{t}$} & \multirow[b]{2}{*}{ Siq. } & \multicolumn{2}{|c|}{ Collinearity Statistics } \\
\hline \multicolumn{2}{|c|}{ Model } & $\mathrm{B}$ & Std. Error & & & & Tolerance & VIF \\
\hline \multirow[t]{6}{*}{1} & (Constant) & -.346 & .454 & & -.762 & .448 & & \\
\hline & Profitability & -.327 & .062 & -.492 & -4.268 & .042 & .836 & 1.045 \\
\hline & Bisnis risk & -.593 & .072 & .606 & 8.213 & .000 & .972 & 1.028 \\
\hline & Growth & .005 & .035 & .010 & .138 & .891 & .998 & 1.002 \\
\hline & Company size & -.015 & .033 & .034 & .450 & .054 & .925 & 1.081 \\
\hline & Tanailibity & -.409 & .245 & -.126 & -1.669 & .098 & .928 & 1.077 \\
\hline
\end{tabular}

Based on test results the regression equation of this study is shown below: $\mathrm{CS}=-0.346-0.327 \mathrm{PROF}+0,593 \mathrm{BR}+0.005 \mathrm{GR}-0,015 \mathrm{FS}-0,408+\varepsilon$

\section{Profitability Relation with Funding Decision}

Profitability describes the success of company to achieve operating profit with a number of assets used for business activities. The test results show that profitability has a significant negative relationship with funding decision. This confirms that higher SMEs profit more likely use internal funding sources of operating income to finance business activities than debt. These findings support the packing order theory to prioritize the use of internal sources and followed with external sources of funds in form of debt for the addition. This study is consistent with empirical studies supporting packing order theory of Akhtar \& Oliver (2009), Crinigoj \& Mramor (2009), Huang \& Song (2006), Tong \& Green (2005), Chen (2002) and Pandey (2001).

\section{Business Risk Relations with Funding Decisions}

Business risk describes the fluctuations in sales and or profits achieved by company in each period of company's operations. Non-debt companies have a higher level of business risk. Therefore, companies reduce the high risk of business with lower debt usage. 
The test results show that business risk has a significant negative relationship with debt funding decisions. This indicates that SMEs in Batu City tend to reduce the debt usage in face of high profit fluctuation. It illustrates high uncertainty and better to use internal fund sources to avoid financial risk of high interest expense. The study findings support Akhtar \& Oliver (2009) study, Crinigoj \& Mramor (2009) who found a significant positive relationship between business risk and capital structure.

\section{Company Growth}

Growth shows a good development in company's business activities, both sales growth, asset growth and profit growth. The test results show that growth has no significant relationship with funding decision. This confirms that company with good growth in business activities will not become determinant in funding decision. The SME actors are more likely to use internal funding sources when sufficient to finance the growth of company's business. This study is inconsistent with results of Cathoth and Olsen (2007), Parlak (2010) study that growth positively associated with debt use.

\section{Company size}

Company size describes the company assets size. Companies with large assets have greater collateral and easier to get sources of debt than small companies. Test results show that company size has a significant negative relationship with funding decision. This indicates that although company assets are increasing, SMEs in Batu City tend to reduce debt funding. In other words, SME players rely more on internal sources of funds than debt. This is because of limited accessibility of SMEs to formal financial institutions (banks). This study is consistent with results of Akhtar \& Oliver (2009), Crinigoj \& Mramor (2009), Huang \& Song (2006), Gaud et al. (2006), Tong \& Green (2005), Chen (2004) and Pandey (2001) to find a positive relationship between company size and capital structure.

\section{Tangibility.}

Tangibility describes the amount of tangible assets owned to support the company's business activities. It also shows the amount of collateral for creditor to use debt to fund the business activities of company. Based on test results show that tangibility has no significant relationship with funding decision. It is evident that most of SME's production activities in Batu City have reached full capacity, even there is no desire to increase the existing production capacity due to limited internal funding sources. These findings support the results of Sumiati (2011) to find no relationship between tangibility and capital structure. However, it is inconsistent Akhtar \& Oliver (2009), Crinigoj \& Mramor (2009), Huang \& Song (2006), Gaud et al. (2006), Zou \& Xiao (2006), Tong \& Green (2005), and Chen (2004).

\section{CONCLUSION}

Many funding decisions of SMEs in Batu City prioritise the internal funding sources. Although the SMEs achieve growth, profit and increased assets, but it is not necessarily encourage them to increase the debt usage. Generally SMEs prioritize the use of internal resources. Although most SME production activities in Batu City have reached full capacity, there is no desire to increase the existing production capacity due to limited internal funding sources. The results of this study are expected to be inputs for stakeholders, especially policy makers to increase the competitiveness of SMEs in order to provide facilities for increasing production capacity of SMEs. However, due to limitations of secondary data owned by SMEs, then for subsequent research is expected to use secondary data related financial data from results of SME business activities.

\section{REFERENCES}


Absah, Yeni. (2008). Kompetensi Sumber Daya Pendorong Keunggulan Bersaing Perusahaan. Jurnal Manajemen Bisnis, Volume 1, Medan.

Arikunto, S. (2013). Prosedur Penelitian Suatu Pendekatan Praktik. Jakarta: PT.Rineka Cipta

Azis, M. Abdul. (2016). Pengaruh Motivasi Kerja, Disiplin Kerja Dan Lingkungan Kerja Terhadap Kinerja Melalui Kepuasan Kerja Pada Pegawai Puskesmas Kecamatan Balapulang Kabupaten Tegal. MULTIPLIER - Vol. I No. 1, PP: 99-108.

Bacal, Robert. (2012), Performance Management. Jakarta: Gramedia.

Cargas, Sarita, Sheri Williams and Martina Rosenberg. (2017). An approach to teaching critical thinking across disciplines using performance tasks with a common rubric. Thinking Skills and Creativity 26, halaman: 24-37

Dai. (2018). A double-edged sword: How and why resetting performance metrics affects motivation and performance Organizational Behavior and Human Decision Processes, Vol. 148, halaman 12-29.

Dwiyanti, Dyah Nur dan Endi Sarwoko. 2015. Pengaruh Motivasi Kerja Terhadap Disiplin Kerja dan Dampaknya Terhadap Kinerja Karyawan (Studi Pada PT. PG. Krebet Baru). Jurnal Riset Mahasiswa Manajemen (JRMM), Volume 3, No. 1, halaman 111.

Elaine S.C. Liu, Carmen J. Ye, Dannii Y. Yeung. (2015). Effects of approach to learning and self-perceived overall competence on academic performance of university students. Learning and Individual Differences, Volume, halaman : 199-211

Fauzi, Usman (2014) Pengaruh Kompensasi Terhadap Kinerja Karyawan Pada Pt. Trakindo Utama Samarinda. eJournal IImu Administrasi Bisnis, Volume 2 Nomor 3 halaman 172 - 185

Ferdinand, Augusty. (2014). Metode Penelitian Manajemen. Semarang: Badan Penerbit Universitas Diponegoro.

Ghozali, Imam. (2007). Aplikasi analisis Multivariate dengan Program SPSS. Semarang: Badan Penerbit UNDIP.

Gujarati, D. N. (2013). Dasar-dasar Ekonometrika, Edisi Kelima. Mangunsong, R. C., penerjemah. Jakarta: Salemba Empat.

Handoko, T. Hani. (2014). Manajemen Personalia dan Sumber Daya Manusia. Yogyakarta: BPFE

Hasibuan, Malayu. (2013). Manajemen Sumber Daya Manusia. Jakarta: PT. Bumi Aksara. https://www.kemenkeu.go.id/apbn2017, diakses 9 September 2018

https://tirto.id/target-pajak-antara-ambisi-dan-realisasi-A, diakses 9 September 2018

https://www.cnnindonesia.com/ekonomi/20180102183322-532-266156/penerimaanperpajakan-hanya-91-persen-dari-target-di-2017, diakses 9 September 2018

KMK. (2004). Keputusan Menteri Keuangan Republik Indonesia Nomor : 254/KMK.01/2004 tanggal 24 Mei 2004 tentang Organisasi dan Tata Kerja Kantor Wilayah Direktorat Jenderal Pajak.

Mahsun, Mohamad. (2009). Pengukuran Kinerja Sektor Publik (3th ed). Yogyakarta: BPFE.

Makawi, Umar, Normajatun dan Abdul Haliq. (2015). Analisis Pengaruh Kompetensi Terhadap Kinerja Pegawai Dinas Perindustrian Dan Perdagangan Kota Banjarmasin. Al - Ulum Ilmu Sosial dan Humaniora, Volume 1 Nomor 1, pp: 1726.

Mangkunegara. Anwar Prabu. (2013). Manajemen Sumber Daya Manusia. Bandung: Remaja Rosdakarya.

Manullang. (2014). Dasar-Dasar Manajemen. Ghalia Indonesia

Mathis, Robert L. dan Jhon H. Jackson. (2012). Manajemen Sumber Daya Manusia. Edisi Kespuluh - Jakarta : Selemba Empat.

Nawawi. (2003). Manajemen Sumber Daya Manusia Untuk Bisnis yang. Kompetitif. Yogyakarta: Gadjah Mada University Press.

Nunally, J. C. (1978). Psychometric Theory, New York,Mc Grow Hill. 
Priyatno, Dewi. (2008). Mandiri Belajar SPSS - Bagi Mahasiswa dan Umum, Yogyakarta: MediaKom

Rahmi, Anggita Ulfazia dan Puspita Wulansari. (2017). Pengaruh Kompetensi Pegawai Dan Motivasi Kerja Terhadap Kinerja Pegawai Dinas Pendidikan Pemuda Dan Olahraga Kabupaten Kuningan. e-Proceeding of Management: Vol.4, No.2, PP: 1359-1365

Ranupandojo dan Suad Husnan. (2000). Manajemen Personalia. Yogyakarta: BPFE.

Robbins, S.P dan Judge T.A. (2015). Perilaku Organisasi. Jakarta: Salemba Em

Robbins, Stephen P. and Timothy A. Judge. (2008). Organization Behavior (Perilaku Organisasi). Diterjemahkan oleh Diana Angelica dkk. Jakarta: Salemba Empat.

Robertson, GL. (2009). Food Packaging and Shelf Life: A Pratical Guide. CRC. Press

Rumanti, Assumpta Maria. (2009). Dasar-Dasar Public Relations : Teori dan ... Keyakinan. Salemba Empat, Jakarta, 2009

Solimun. (2011). Analisis Multivariat Pemodelan Struktural Metode Partial Least Square PLS. Edisi Pertama. Malang: CV Citra MalangSouth Western College Publishing

Sugiyono. (2014). Metode Penelitian Kuantitatif, Kualitatif, dan R\&D. Bandung: CV Alvabeta

Supranto, J. (2011). Pengukuran Tingkat Kepuasan Pelanggan Untuk. Menaikkan Pangsa Pasar ( Cetakan Keempat). Jakarta : PT. Rineka Cipta.

Supriyanto Abdi. (2009). Potret Pemenuhan Hak atas Pendidikan dan perumahan di era Otonomi Daerah. Yogyakarta: PUSHAM UII.

Susilo. Martoyo. (2007). Manajemen Sumber Daya Manusia. BPFE. Yogyakarta.

Suyanto (2018). Competence and Discipline on Work Motivation and the Implication on Working Performance. European Research Studies Journal Volume XXI, 1, halaman 570-587.

Tugiman. (2014). Pengaruh Kedisiplinan Dan Kepemimpinan Terhadap Motivasi Kerja Dan Kinerja Guru Smp Negeri 1 Piyungan. Aktual, Vol.1 N0.2. PP: 69-83.

Whittaker, James O. (2009). Introduction to Psychology. (London: W.B. Sounders.

Wibowo. (2013). Manajemen Kinerja. Edisi Ketiga. Jakarta: PT Raja Grafindo. Persada. 